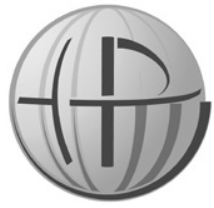

Horyzonty Polityki 2019, Vol. 10, No 33

OPEN ACCESS

\section{Wit Pasierbek}

http://orcid.org/0000-0002-8774-4461 Akademia Ignatianum w Krakowie Instytut Nauk o Polityce i Administracji wit.pasierbek@ignatianum.edu.pl

DOI: 10.35765/HP.2019.1033.01

\title{
Uszanowanie charakteru władzy w średniowieczu
}

\section{Streszczenie}

CEL NAUKOWY: Celem naukowym niniejszego artykułu jest ukazanie charakteru władzy i szacunku do niej w pierwszych wiekach nowożytnej ery.

PROBLEM I METODY B AD AWCZE: Ponieważ dzisiaj władzy politycznej raczej się nie szanuje, warto się zastanowić nad tym fenomenem, analizując pierwsze wieki chrześcijaństwa i stawiając pytanie: jaki był charakter ówczesnej władzy? Odpowiedzi będziemy szukać, analizując główne nurty myśli teologiczno-politycznej tamtych czasów.

PROCES WYWODU: Wychodząc od początków ludzkiego istnienia i potrzeby uporządkowania świata $\mathrm{z}$ chaosu spowodowanego grzechem, przeanalizowany zostanie charakter władzy pierwszych wieków chrześcijaństwa i średniowiecza. Począwszy od Jezusa Chrystusa, naukę św. Pawła, a później trzech wariantów rządów według Euzebiusza z Cezarei, św. Augustyna oraz św. Ambrożego i św. papieża Gelazego I, będziemy dowodzić, iż władza bierze swój początek w Bogu, by później poprzez władzę Kościoła i cesarza zaprowadzać porządek i pokój w świecie.

WYNIKI ANALIZY NAUKOWEJ: Analiza poglądów schyłku starożytności i średniowiecza dowodzi, iż istniały trzy rodzaje rozumienia władzy: prymat cesarza przy współudziale Kościoła (Euzebiusz z Cezarei), wyrazista wyższość władzy kościelnej nad świecką i pogańską (św. Augustyn) oraz rozdział pomiędzy władzą kościelną i świecką (św. Ambroży i św. papież Gelazy I). 
WNIOSKI, INNOWACJE, REKOMENDACJE: Analiza charakteru władzy z pierwszych wieków chrześcijaństwa i średniowiecza dowodzi, iż powszechnie okazywano szacunek zarówno władzy kościelnej, jak i świeckiej, uzasadniając taką postawę jej boską naturą i jednocześnie troską o dobro wspólne. Mądrość, która płynie od chrześcijańskich i średniowiecznych myślicieli, winna być zatem poważnym bodźcem do refleksji nad charakterem i stosunkiem do władzy we współczesnej cywilizacji demokratycznej.

\section{SŁOWA KLUCzowe:}

władza, średniowiecze, Augustyn, Gelazy I, Euzebiusz z Cezarei

\section{Abstract}

\section{RESPECT FOR AUTHORITY IN THE MIDDLE AGES}

RESEARCH OBJECTIVE: The research objective of the article is to present the nature of authority and respect it enjoyed in the first centuries of the modern era.

THE RESEARCH PROBLEM AND METHODS: As political authorities are hardly respected today, it is worth reflecting on the phenomenon of authority by analysing it in the first centuries of Christianity and posing the question: what was the nature of authority in this period? The answer to it will be sought by analysing the main areas of the theological-political thought of that time.

THE PROCESS OF ARGUMENTATION: Starting with the beginnings of human existence and the need to give order to the world in chaos caused by sin, we will analyze the nature of authority in the first centuries of Christianity and the Middle Ages. Beginning with the teachings of St. Paul, and three models of the government advocated by: Eusebius of Caesarea, St. Augustine, and St. Ambrose and St. Pope Gelasius I, we will prove that authority comes from God and through the authority of the Church and the emperor, brings order and peace to the world.

RESEARCH RESULTS: The analysis of the views of the thinkers of the Middle Ages reveals three ways in which they undertsood authority: the primacy of the emperor with the participation of the Church, superiority of ecclesiastical authority over secular and pagan authority and the separation between ecclesiastical and secular authorities.

CONCLUSIONS, INNOVATIONS, AND RECOMMENDATIONS: The analysis of the nature of authority in the Middle Ages demonstrates that respect for both ecclesiastical and secular power was widespread and was justified by its divine nature and by concern for the common good. Thus, the wisdom of 
Christian and medieval thinkers should serve as stimulus to reflect on the nature and the attitude to authority in modern democratic civilization.

\section{SŁOWA KLUCzowe:}

authority, Middle Ages, Augustine, Gelasius I, Eusebius of Caesarea

Dlaczego dzisiaj, dość powszechnie, nie szanuje się władzy, szczególnie w kulturze zachodniej, której fundamenty są iście chrześcijańskie i demokratyczne? Oczywiście, przyczyn można byłoby podawać bez liku: jedne bardziej słuszne, inne zaś przepełnione nieuporządkowanymi uczuciami, nieracjonalnymi argumentami i ogólnie panującą wszechwiedzą. A skoro tak, to dlaczego mamy władzę respektować?

Dziwne w tym wszystkim jest jednak to, że właśnie chrześcijaństwo naucza, iż władzę należy poważać i być jej posłusznym. Skąd bierze się takie przekonanie?

W szukaniu odpowiedzi na ten problem będziemy się posiłkować okresem średniowiecza, który rozciągał się bez mała przez dziesięć wieków (V-XV), a szczególnie wczesnym jego periodem. Niniejsze, średniowieczne dywagacje dadzą nam tylko część prawdy o władzy, ale warto się temu przyjrzeć, tym bardziej że jest to połowa czasu ery nowożytnej.

\section{KRÓTKI EXCURSUS HISTORYCZNO-BIBLIJNY}

Jak podaje Księga Rodzaju (rozdz. 2-3), rajskie nieposłuszeństwo Adama i Ewy (grzech pierworodny) wprowadziło zamęt $w$ ich relacjach z Bogiem, ale także w ich rodzinie (Kain zabija Abla, rozdz. 4). Konsekwencją tego wszystkiego była symboliczna Wieża Babel (rozdz.11), która ostatecznie nie dosięgnęła nieba, jak chcieli jej twórcy, bo Bóg ukarał pychę ludzi, mieszając ich języki. W ten sposób wszedł między nich chaos i niezrozumienie. A chaos i brak zgody prowadzi do konfliktów i ostatecznie wojen oraz zabijania.

W tym zagubieniu Bóg nie pozostawia ludzi samym sobie, tylko stara się ich prowadzić, pouczać, a nade wszystko okazywać im miłość. Efektem tegoż będzie zawarcie unilateralnego przymierza 
Boga z Narodem Wybranym (Rdz 17, Wj 34). Od początku historii człowieka i Narodu Wybranego Bóg im przewodzi, jest dla nich kochającym Władcą i Panem. I nawet jeżeli Abraham czy Mojżesz działają z woli Boga, to On jest Panem. Ta sytuacja utrzymuje się do okresu powstania państwowości Izraela, kiedy zostaje powołany pierwszy król Saul namaszczony przez proroka Samuela (1 Sm 10-11). Jednakże owo powołanie dokonuje się z mandatu Bożego, bowiem każdy król zwany będzie mesjaszem, „Bożym pomazańcem”, "synem Boga”, , który ma namacalnie urzeczywistniać panowanie Boga i Jego zbawczy plan. Powinien zatem być obrońcą słabych i zapewniać ludowi sprawiedliwość; oskarżenia proroków zwracać się będą właśnie przeciwko niedopełnianiu przez królów nałożonych na nich zobowiązań" (Kompendium KNS, 2005, nr 377). Co więcej, Stary Testament podaje charakterystyczne cechy króla: pasterz Izraela, mądry, sprawiedliwy, brzydzi się nieprawością, rzetelnie potrafi osądzać, troszczy się o każdego człowieka, szczególnie biednego (Kompendium KNS, 2005, nr 378). Warto tutaj zaznaczyć, iż król był tylko pośrednikiem pomiędzy prawdziwym Królem i Władcą Izraela - Bogiem a Narodem Wybranym, dlatego jego władza była w pewnym sensie ograniczona, gdyż prawdziwy Władca to Bóg, bo władza od Niego pochodzi.

Takie rozumienie władzy potwierdził sam Jezus Chrystus. Nie miejsce tutaj na różne interpretacje Chrystusowego przywództwa w dwudziestowiecznej historii. Wspomnę tylko, że uznawano Go za reformatora społecznego (C. Meunier, É. Cabet, P.-J. Proudhon), anarchistę (E. Renan, T. Hobbes, H. Spencer i L. Tołstoj), rewolucjonistę - teologia wyzwolenia (J.B. Metz i J. Moltmann, J.H. Cone, R.A. Aloes, G. Alvez, G. Gutierrez), czy jeszcze kogoś innego, w zależności od zapotrzebowania na społeczno-religijne wsparcie często dewiacyjnych poglądów. Tymczasem Jezus Chrystus jest Mesjaszem i Jego misja w niczym nie miała charakteru politycznego, jedynie poprzez „służenie i ofiarowanie życia za innych" (Mk 10,45) oraz bezgraniczną miłość i zrównanie wszystkich przyniósł człowiekowi uniwersalistyczny humanizm ewangeliczny, który winien być podstawą ducha demokracji.

Dla nas ważne jest pytanie: jaki był Jego stosunek do władzy? Ewangelie zdecydowanie podkreślają że Jezus potępiał despotyczną władzę rządzących narodami, a przy tym wykorzystywanie 
i gnębienie poddanych, ale nigdy władzy nie podważał. $Z$ tego też wypływa druga zasadnicza cecha, a mianowicie ten, kto chce przewodzić, mieć władzę, musi być ostatnim i służyć innym (MK 9,33-35). Jest to cecha, która nieustannie się kłóci z naturą władzy pojmowaną przez wieki, a co wypływa z konkretnej antropologii, mianowicie niepohamowanej chęci nadrzędności, wyższości (poczucia bezpieczeństwa?) i jednocześnie podporządkowywania sobie innych.

Dla naszych rozważań najważniejsza jest odpowiedź Chrystusa na pytanie: „czy wolno płacić podatek Cezarowi, czy też nie”? (Mk 12,14). Czyli: czy mamy uznawać władzę Cezara, czy też nie - podchwytliwie pytali faryzeusze. Odpowiedź zaskakuje: „Oddajcie więc Cezarowi to, co należy do Cezara, a Bogu to, co należy do Boga" (Mk 12,17). „Bogu należy oddać to co Boskie, otwarcie potępiając tym samym każdą próbę ubóstwienia i absolutyzacji władzy doczesnej. Tylko Bóg może wymagać wszystkiego od człowieka. Jednocześnie władza doczesna ma prawo do tego, co jej się należy" (Kompendium KNS, 2005, nr 379). Ta odpowiedź Jezusa jest dla nas kluczowa, bowiem od tej pory nauka Kościoła w sprawach władzy politycznej będzie się odwoływać do tych trzech zasadniczych norm: pierwsza dotyczy tego, że władzę trzeba szanować i oddawać jej to, co się jej należy, druga rozdziału pomiędzy władzą Boska, nadrzędna, a ludzka, stanowiona, a trzecia - jej służebnego charakteru, co z mocą podkreślał Chrystus.

Tę naukę Mesjasza odważnie głosili apostołowie, przede wszystkim św. Paweł. Zauważyć trzeba, że wbrew panującemu wówczas przekonaniu o ubóstwianiu władzy i władcy św. Paweł odstępuje od tego, uznając, iż władzę należy szanować. Dzieje się tak z kilku racji. Najpierw trzeba stwierdzić, iż chrześcijaństwo oddziela władzę od osoby ją piastującej. Szacunek bowiem okazywany jest funkcji, którą dana osoba pełni. Sama władza nie jest atrybutem tej czy innej osoby, pochodzi bowiem od Boga: „Nie ma bowiem władzy, która by nie pochodziła od Boga, a te, które sa, zostały ustanowione przez Boga" (Rz 13,1).

Ponieważ władza pochodzi od Boga, należy jej słuchać, tak jak winniśmy posłuszeństwo samemu Bogu, bo władza jest narzędziem, które ma ułatwiać czynienie dobra, a chronić przed złem. Kto więc czyni dobro, nie ma powodu lękać się władzy, jeżeli zaś czyni źle, słusznie jest karany, gdyż władza karząca jest również narzędziem Boga. Należy jednak słuchać władzy nie w nadziei nagrody, ani też 
z lęku przed kara, „, ale ze względu na sumienie” (Rz 13,5). Wszystkie więc świadczenia na rzecz społeczeństwa nakazane przez władzę są obowiązkiem sumienia: „Oddajcie każdemu to, co mu się należy: komu podatek - podatek, komu cło - cło, komu uległość - uległość, komu cześć - cześć" (Rz 13,7) (Majka, 1987, s. 40).

Dlaczego według Pawła to sumienie decydować winno o szacunku i posłuszeństwie wobec władzy? W sumieniu, jak naucza Sobór Watykański II w „Konstytucji o Kościele w świecie współczesnym”, człowiek dokonuje decyzji, za które bierze pełną odpowiedzialność.

Sumienie jest najtajniejszym ośrodkiem i sanktuarium człowieka, gdzie przebywa on sam z Bogiem, którego głos w jego wnętrzu rozbrzmiewa. Przez sumienie dziwnym sposobem staje się wiadome prawo, które wypełnia miłowaniem Boga i bliźniego (16).

Tam też w pełnej szczerości opowiada się za dobrem wspólnym realizowanym przez miłość. Skoro więc władza polityczna, która winna troszczyć się o dobro wspólne obywateli, tak wypełnia swoją misję, byłoby wielce szkodliwe, gdyby człowiek się temu w sumieniu przeciwstawiał. W ten sposób przeciwstawiałby się nie tylko władzy, która jest gwarantem dobra wspólnego, ale samemu Stwórcy, który to wszystko uczynił. A skoro dotyka to źródła wszelakiego dobra, dotyka więc również tego, który Bożemu dobru, miłości się przeciwstawia. Dlatego posłuszeństwo i okazywanie szacunku władzy politycznej nie dotyczy osób ją sprawujących, ale odnosi się do dobra wspólnego i posłuszeństwa woli Bożej. Toteż apostołowie nie tylko uznają władzę rzymską, choć była władzą okupacyjna, ale zachęcają do wypełniania jej rozporządzeń, nakazów, obowiązków obywatelskich w takim stopniu, w jakim odnoszą się one do dobra wspólnego. Gdyby się jednak zdarzyło, że władza stanowiłaby prawa gwałcące godność człowieka, niezgodne z prawem Bożym, namawiała do czynienia zła, wówczas należałoby się temu przeciwstawić, jednakże nie w formie zbrojnych, krwawych działań, chęci obalenia władzy, ale poprzez odrzucenie tego, co się godności człowieka i wspólnemu dobru sprzeciwia.

I tutaj pojawia się istotny dla nas wątek, wyżej już wspominany, a mianowicie sprawa sumienia. Paweł stwierdził, że władzy należy słuchać „ze względu na sumienie”. Władza polityczna i w ogóle jakakolwiek nie ma prawa do sumienia człowieka, nie może $w$ to 
„sanktuarium” ingerować w żaden sposób. Nikt nie ma tam władzy. Sumienie bowiem niezaprzeczalnie stanowi o ludzkiej godności. Władza rzymska nie posiada więc żadnych kompetencji w kwestii sumienia. A skoro tak, to jedyną władza, która z Bożego mandatu takie kompetencje posiada, jest ustanowiony przez Jezusa Chrystusa Kościół. I tutaj znajdujemy punkt wyjścia do rozważań na temat szacunku, posłuszeństwa władzy, które w okresie średniowiecza było niepomierne.

\section{WŁADZA KOŚCIOŁA I CESARZA WE WCZESNYM ŚREDNIOWIECZU}

Chrystus, odpowiadając na pytanie o płacenie podatku Cezarowi, wskazuje na rozdział pomiędzy tym, co Boskie, i tym, co cesarza, czyli ludzkie. Ten podział dzieli władzę na dwie fundamentalne strefy: duchowa, religijna, transcendentną i materialna, ziemska, ludzką. Nauka apostołów kontynuuje konsekwentnie ten podział na podstawie tworzącej się wspólnoty i organizacji Kościoła, bo tylko Kościół posiada "dostęp" do ludzkich sumień, troszcząc się o dobro i zbawienie dusz. Tymczasem zadaniem władzy świeckiej, czyli państwa, jest troska o dobra materialne i doczesne.

Pomimo krwawych prześladowań chrześcijan w pierwszych wiekach nowej ery ta doktryna w niczym się nie zmienia. Co więcej, w pewnym sensie się utrwala, doprowadzając do symbiotycznego istnienia władzy kościelnej z władzą świecką. W roku 313 cesarz zachodniej części Imperium Rzymskiego Konstantyn Wielki oraz cesarz wschodniej części tegoż Imperium Licyniusz wydali edykt mediolański zezwalający na swobodne wyznawanie wiary chrześcijańskiej. Było to wydarzenie bezprecedensowe. Do tego cesarze Gracjan, Walentynian II i Teodozjusz I wydali w roku 380 w Tesalonikach edykt ustanawiający chrześcijaństwo w imię Trójcy Świętej religia państwową Imperium Rzymskiego. Te dwa konstytutywne fakty historyczne zdają się potwierdzać naukę apostołów.

Czy tak rzeczywiście było? Chciejmy wyłowić z nauki okresu wczesnego średniowiecza kilka zasadniczych elementów, które pozwoliłyby nam lepiej zrozumieć miejsce Kościoła i władzy politycznej w świecie. Z tym wiąże się poszukiwanie odpowiedzi na postawioną 
hipotezę: czy w tym okresie rzeczywiście Kościół potwierdzał w swoim nauczaniu doktrynę rozdziału władz i jednocześnie szacunku oraz posłuszeństwa władzy świeckiej?

Z powyższych dywagacji, czyli nauki Chrystusa i Pawła oraz historycznych faktów dotyczących wolności i państwowości religii chrześcijańskiej, można wysnuć trzy zasadnicze nurty rozumienia władzy. Jak podaje M. Scattola, układają się one w trójkąt: Bóg, Kościół i polityka/władza świecka, albo Bóg, Chrystus i cesarstwo. Bóg-Transcendencja jest całkowicie nadrzędny i dzieli świat na dwa rozłączne obszary: królestwo Boże, wieczne i królestwo ziemskie, grzeszne, doczesne. Drugim obszarem jest Kościół Chrystusowy, który zrodził się ze wspólnoty zgromadzonej wokół Krzyża i Zmartwychwstania, a centrum tychże wydarzeń jest Eucharystia, która zespala i tworzy mistyczne Ciało Chrystusa (Kościół). Zarówno Chrystus, jak i Jego Kościół stają się niejako Pośrednikiem i Zwornikiem pomiędzy Bogiem i grzesznym światem. I trzeci obszar, królestwo ziemskie, natura, grzech i doczesność. Chrześcijanie do tego świata nie należą, bo zostali wybrani już przez Chrystusa, ale w tym świecie żyją (Scattola, 2011). W związku z tym muszą się w nim odnaleźć poprzez jakiś konkretny i skuteczny modus vivendi. Stąd szacunek i posłuszeństwo władzy, co mocno podkreślał Paweł. Jednakże owo posłuszeństwo musi być w pełni świadome i dokonywać się w sumieniu, czyli poprzez wewnętrzny osąd, a tam ma prawo tylko Bóg i Jego „reprezentant” - Kościół. Oczywiście, w tamtym okresie Kościół uczynił się takim „pośrednikiem” i niekiedy utrudniał wierzącemu osobisty kontakt z Bogiem, jednakże nie było to zasada, tylko bardziej „słabością".

Owe trzy obszary, w których transcendencja Boga, władza Kościoła i władza świecka (cesarza) w jakiś sposób wchodzą w kontrakcję, domagają się wyjaśnienia i konkretnego ulokowania. A przede wszystkim odpowiedzi na pytanie: w jaki sposób pomagają człowiekowi w umiejętności rozeznawania pomiędzy dobrem a złem, czyli tworzeniu takich warunków życia, by było one szczęśliwe? Tutaj spotyka się porządek boski z porządkiem ludzkim, a co za tym idzie charakter władzy.

Ówczesne nurty filozoficzno-teologiczne w głównej mierze opierały się na tradycji filozofii stoickiej i neoplatońskiej oraz rodzącej się teologii apologetycznej pierwszych wieków. A chodziło w nich 
głównie o rolę Logosu (wcielonego Słowa Boga - Jezusa Chrystusa) z prologu Ewangelii według św. Jana (1,1-18). Ów Logos, odwieczne Słowo Boga, jest tym, który ma doprowadzić do uporządkowania świata z chaosu spowodowanego ludzkim nieposłuszeństwem, grzechem. Pytanie, które wówczas stawiano, dotyczy obecności, objawiania się i wpływu Logosu na władzę zarówno kościelną jak cesarska/ imperialną.

Odnieśmy to teraz do owych trzech obszarów, co pozwoli nam zrozumieć charakter władzy i jej systematyzowanie. Jednocześnie pokaże nam, w jaki sposób ewoluowała koncepcja władzy, już to na przestrzeni wieków, już to koncepcyjnie.

\section{EUZEBIUSZ Z CEZAREI - IMPERATOR PONAD WSZYSTKO (IMPERIUM WSCHODNIE)}

Euzebiusz z Cezarei (256-337), uznawany za pierwszego historyka Kościoła, był wielkim wielbicielem cesarza Konstantyna Wielkiego i w dwóch dziełach (De laudibus Constantini wychwalający Imperatora Konstantyna oraz Teophania traktująca o Logosie i Odkupieniu) przedstawia słuszność połączenia władzy kościelnej i cesarskiej, tzw. cezaropapizm. Gloryfikacja cesarza nie jest skutkiem tylko wydanego przez niego edyktu mediolańskiego, ale pewnej zmiany rozumienia natury władzy. Wiek III n.e. był poważnym zagrożeniem upadku Imperium Rzymskiego, przez co ówcześni cesarze wprowadzili totalitarny system zarządzania, często bardzo okrutny. Wraz z nowym ustrojem władzy następuje apoteoza imperatora (mocno obecna w starożytnym hellenizmie i pogaństwie), często przypisująca mu charakter religijny, ale zmieniła się jej natura. Otóż z końcem III w. następuje duchowa rewolucja w Imperium, nazywana drugą lub odnowioną fazą religijności. Hellenistyczny politeizm zastępuje chrześcijański monoteizm. Odkrywa się inne rozumienie sacrum, które według starożytnego pogaństwa pojmowało bóstwo w formie neutralnej ( (ò $\theta \varepsilon i ́ o v)$, natomiast wraz z chrześcijaństwem wchodzi nowa idea Boga (ó Đeós), który jest Osobą, Absolutem, Transcendencją źródłem i zasadą wszystkiego. Taki Bóg jest przedmiotem miłości, szacunku i adoracji. W takim kontekście religijnym należy rozumieć pozycję cesarza u początku średniowiecza. Wyobrażenie 
boga w czasach pogańskich nie było trudne, więc „ubóstwianie” cesarzy skupiało się bardziej na przyziemnej, wyobrażalnej sferze ludzkich doświadczeń. Kult cesarza ograniczał się do przyrównywania do boga, którego łatwo można było sobie wyobrazić, korzystając z całej plejady panteonu bogów hellenistycznych i rzymskich. Granica pomiędzy tym, co ludzkie, i tym, co boskie była bardzo nieznaczna. Od IV w. jednak zmienia się charakter kultu cesarza, począwszy od Konstantyna, bowiem przyznawanie imperatorowi atrybutów religijnych wynosi go zdecydowanie ponad ludzką sferę i wprowadza w świat Boga, transcendencji, dla człowieka nieznany i niedoświadczalny (Daniélou i Marrou, 1986).

Tak też pojmuje pozycję imperatora Konstantyna Euzebiusz z Cezarei. W swoim rozumowaniu wychodzi od stwierdzenia, iż wszechświat stworzony przez zamysł Boży jest uporządkowany. Wiekuiste Słowo Boga (Logos) jest pośrednikiem pomiędzy Nim a wszechświatem. Jego zadaniem jest przywrócić porządek i ład w świecie, który został naruszony poprzez grzech człowieka. Dzieje się to w dwojaki sposób: poprzez Wcielenie - Jezus Chrystus oraz kierowanie ziemskimi dziejami poprzez niewidzialny umysł. Logos usunął wszelakie fałszywe bóstwa politeizmu, zaś lud rzymski pod przywództwem imperatora zjednoczył rozliczne miasta świata. Dlatego należy przyjać, iż w dziele odkupienia ma udział także Imperium Rzymskie, które antycypuje zjednoczenie ludzkości i zaprowadzenie ładu powszechnego. Można zatem już uważać, że cesarstwo jest prawdziwą społecznością kościelna, gdyż taką funkcję pełni. Następuje tutaj połączenie wspólnoty kościelnej ze wspólnotą polityczna, świecka, które odtąd stanowią jedno pod przywództwem cesarza.

Jeżeli boski Logos oddziałuje w historii tak samo bezpośrednio, jak manifestuje się w Objawieniu, to musi być czynny jednakowo w Zbawicielu i w cesarzu - jednakowo, ale oczywiście w różnym stopniu. Dlatego Euzebiusz w prologach do dwóch części „Pochwały” oznajmia, że chce wysławiać Konstantyna nie z racji jego zasług wojennych i politycznych, lecz dla jego książęcych przymiotów, które odsyłają do tajemnej więzi łączącej władzę ziemską z jej odwiecznym źródłem. Majestat jest bowiem pierwotnie atrybutem boskim, odpowiadającym niebieskiej światłości, która otacza Wszechmocnego (Scattola, 2011, s. 50). 
Choć rozumowanie Euzebiusza nosi wiele znamion słuszności, to jednak przypisywanie władzy cesarza mocy boskiej bez sakramentalnego zapośredniczenia, jak to się dzieje w wypadku władzy kościelnej (papież i biskupi), rodzi pewne wątpliwości. Bowiem w Kościele powszechnym piastowanie władzy zakłada wiarę ją sprawującego. Wynika to z mandatu sakramentu święceń. Nie ma czegoś takiego w wypadku cesarza. Co więcej, cesarz staje się głową Kościoła wschodniego i pierwsze sobory ekumeniczne, ustanawiające doktrynę Kościoła, otwierane były zawsze przez cesarza, przypisując mu rolę ostatecznego decydenta.

\section{ŚWIĘTY AUGUSTYN - PAŃSTWO BOŻE I PAŃSTWO ZIEMSKIE (CESARSTWO RZYMSKIE ZACHODNIE PIERWSZYCH PIĘCIU WIEKÓW)}

Zgoła odmiennego zdania był biskup Hippony św. Augustyn (354-430). W jego nauczaniu nie ma istotnego miejsca na znaczącą rolę cesarza i państwa świeckiego w dziejach zbawienia świata. Jedyne objawienie się boskiego Logosu dokonuje się w Jezusie Chrystusie. Cesarz nie ma w tym żadnego udziału. To poprzez śmierć i zmartwychwstanie Jezus Chrystus odkupił ludzkość i założył Kościół, który jest widzialnym pośrednikiem pomiędzy Bogiem a światem. Tę rolę pośrednictwa w szczególny sposób sprawuje papież i biskupi. Dlatego Augustyn mówi o dwóch odrębnych bytach: państwie ziemskim, które kieruje się miłością własna, samolubstwem i żądzą podbojów, oraz państwie Bożym, niebieskim, chrześcijańskim, które kieruje się sprawiedliwością i miłością (Augustyn, 1977). Oba państwa reprezentują odmienne porządki: ziemski - immanencja oraz boski - transcendencja. Jednakże to Bóg jest wszechmocny i kieruje historią zbawienia, która dotyczy także owego grzesznego świata. On może pokierować jego losami i także z grzechu wyciągnąć dobro. Bóg ostatecznie decyduje o zbawieniu, a więc o przeznaczeniu tych, których wybrał (święci, państwo Boże) i którzy będą potępieni (grzesznicy, państwo ziemskie) (Brown, 1992).

Czy jednak Augustyn tak negatywnie patrzył na państwo ziemskie, nie dostrzegając w nim żadnych pozytywnych elementów? Myliłby się ten, kto tak by twierdził. Nie można odmówić św. Augustynowi 
zdrowego rozsądku i realizmu życia, bo przecież ci, którzy są wybrani, i ci, którzy o to muszą się starać, wszyscy żyją w doczesnym świecie ziemskim, oczekując na przejście do wiecznej chwały. Jaką więc rolę państwu ziemskiemu przypisywał Augustyn?

Państwo określa jako res communis, res populi. A skoro tak, to naczelnym celem państwa jest troska o dobro wspólne obywateli. „Lud jest wielką rozumną gromadą zespoloną przez zgodną jedność w umiłowanych przez się sprawach" - pisał św. Augustyn we wspomnianym dziele. Dlatego władza winna się o te „umiłowane sprawy” troszczyć, postępując zgodnie z wymogami moralności, stwarzając warunki do godnego i spokojnego życia. W takim razie pierwszym zadaniem państwa i władzy jest troska o pokój zewnętrzny i wewnętrzny narodu. A pokój zależy od sprawiedliwości i ostatecznie miłości, którymi winna kierować się władza i które muszą stać u podstaw państwowości. Jest to naturalna skłonność wszystkich ludzi, bowiem każdy pragnie pokoju. Pokój natomiast zależy od harmonii właściwego współistnienia i współpracy wielu czynników, które ostatecznie tworzą ład i porządek. Porządek ten (ordinatio) winien obejmować wszystkie szczeble współżycia społecznego od rodziny aż do stosunków między narodami, opierając się na wspomnianych zasadach sprawiedliwości i miłości. Majka twierdzi, że św. Augustyn sformułował postulat, proponując, by stosunki między państwami były regulowane na zasadzie prawa i hierarchii władzy. A to są główne zasady stosunków międzynarodowych, więc sugeruje, by uważać go za prekursora nie tylko prawa międzynarodowego, którego podstawą powinno być prawo boskie, naturalne i objawione, ale także jakiejś organizacji narodów, a nawet władzy ponadnarodowej (Majka, 1987).

Obywatele państwa Bożego winni zabiegać o pokój niebiański, ale aby tak było, muszą najpierw osiągnąć pewien pokój ziemski. Dlatego oba państwa powinny posługiwać się tymi samymi rzeczami doczesnymi, ale z odmiennymi celami: państwo ziemskie zabiegać będzie o właściwe prawa, posłuszeństwo i porządek wśród obywateli, których celem jest życie doczesne, śmiertelne, zaś państwo Boże korzystać będzie z praw świeckich i jego pokoju tylko na krótki okres ziemskiej egzystencji. Z takiego rozumowania można byłoby wysnuć wniosek, iż państwo ziemskie, w pewnym czasowym, doczesnym stopniu, jest potrzebne państwu Bożemu. Augustyn jednak tak nie 
uważa. Twierdzi, że jeżeli pokój osiąga się przez sprawiedliwość, to ta jest tylko u Boga. Tylko ten, kto czci i wierzy w Boga, może zaprowadzać sprawiedliwość na ziemi i harmonię wśród ludzi. Dlatego żadna władza polityczna, żadne ziemskie państwo nie może gwarantować pokoju i sprawiedliwości, bo czci fałszywe bóstwa i pała pożądliwością zła i grzechu, dbając o własne interesy. Dlatego Augustyn domaga się postawy wiary i kultu w polityce i sprawowaniu władzy. Ład społeczny może wprowadzić tylko człowiek wierzący, wyprowadzając go z ładu Bożego.

Drugi argument, który wysuwa, dotyczy permanentnego konfliktu i napięcia, które istnieje pomiędzy państwem Bożym i państwem ziemskim. Władza polityczna, ziemska nie jest w stanie zapewnić właściwego, moralnego, zgodnego z Bożymi przykazaniami życia. Stąd święci nie potrzebują państwa ziemskiego, bowiem zostaną zbawieni niezależnie od niego. Ten antagonizm znajduje swoje odzwierciedlenie $\mathrm{w}$ dziejach historii, którymi kieruje wszechmocna wola Boża. Historia państwa ziemskiego jest stała, bez żadnego celu, niezmienna. Natomiast państwo Boże jest ponad tym wszystkim. Augustyn zauważa, że w świeckiej historii można zauważyć znamiona Bożej sprawiedliwości i państwo ziemskie powstaje z woli Bożej. Nawet jednak jeżeli Boża interwencja jest tutaj widoczna, to państwo ziemskie nie ma większego znaczenia w dziejach zbawienia (Augustyn, 1977, V 1, t. 1; V 13, t. 1).

Nie istnieje plan historii, który obejmowałby cały świat - chrześcijański i pogański - w jednym projekcie. (...) Jeżeli państwo świętych jest wspólnotą wybraną przez Boga, żyjącą w oczekiwaniu końca, to królestwo nie może spełniać względem niego nawet funkcji negatywnej, jak gdyby państwo miało zapewnić minimalne warunki porządku, konieczne dla przetrwania państwa Bożego. Z powodu tej asymetrii Kościół Chrystusowy musi walczyć w historii, ale nie może zwyciężyć w czasie. Niewątpliwie przewyższa on królestwo, ale nie może rościć sobie pretensji do żadnego zadania kierowniczego w porządku doczesnym, ponieważ obydwie sfery pozostają ściśle rozdzielone (Scattola, 2011, s. 56).

Warto jeszcze zauważyć, że Augustyn przypisywał państwu i władzy rolę opiekuńczą bowiem powinno się ono troszczyć o wspólne dobro i dobro poddanych. Dobro wspólne uzasadnia przywilej domagania się od nich posłuszeństwa. Tak rozumiana władza jest niezbędna 
i jej potrzeba wynika z konieczności porządku społecznego oraz realizacji dobra wspólnego, implikującego dobro poddanych. Bez tak rozumianej władzy współżycie społeczne byłoby niemożliwe i w takim sensie pochodzi ona od Boga. Do tego jeszcze trzeba dopowiedzieć, iż Augustyn uważa, że czynnikiem tworzącym wspólnotę, społeczeństwo na gruncie dobra wspólnego jest rozumna natura człowieka, która tak właśnie została stworzona przez Boga. A skoro tak, to mamy tutaj teorię pośredniego pochodzenia władzy od Boga.

Cały namysł Augustyna nad władza, państwem służył jednemu celowi: pragnął on stworzyć państwo stricte chrześcijańskie, przeciwstawiając je państwu pogańskiemu, czego tak bardzo boleśnie sam doświadczał. I nawet jeżeli zdecydowanie oddzielał obie władze, to $\mathrm{z}$ racji boskiego pochodzenia władzy politycznej miał ją w poszanowaniu i jak dowodziliśmy, znajdował wiele dobrego w jej działaniach.

\section{ŚWIĘCI AMBROŻY I PAPIEŻ GELAZY I - POKOJOWY ROZDZIAŁ KOŚCIOŁA OD KRÓLESTWA (CESARSTWO RZYMSKIE W ŚREDNIOWIECZU)}

Z doktryną św. Augustyna nie zgadzał się najpierw św. Ambroży (339-397), biskup Mediolanu. Był on zagorzałym obrońcą niezależności Kościoła, podtrzymując w ten sposób autonomię dwóch władz. Twierdził, że za to, co dotyczy religii w sprawach wiary i administracji kościelnej, odpowiada biskup, który z Bożego mandatu to czyni. Gdyby zdarzył się przypadek niewierności lub innych odstępstw cesarza, wówczas biskup nie tylko winien się temu przeciwstawić, ale w wypadkach koniecznych użyć nawet ekskomuniki. Kościół musi być niezależny i autonomiczny, zaś „,imperator jest w Kościele, a nie ponad Kościołem" - mawiał św. Ambroży. Nawet jeżeli ta wypowiedź Ambrożego wydaje się surowa, to trudno znaleźć drugiego w tamtych czasach hierarchę Kościoła, który by tak bardzo szanował władzę polityczną. Jego stosunek do obu władz był wyjątkowo wyważony, a władzę świecką uważał za pozytywnie konieczną, bowiem jest ona potrzebna dla sprawiedliwego porządku w świecie, chociaż musi uznać ograniczenia, które nadaje Objawienie, wiara chrześcijańska i Kościół. 
Tę myśl 100 lat później kontynuował i dopracował papież Gelazy I (?-496). Namiestnikiem Chrystusa na ziemi był tylko cztery lata, ale zdążył zaznaczyć swoją obecność i wysnuć zgoła istotną doktrynę pojmowania władzy, którą zawarł w liście do cesarza Atanazego. Jego pogląd był jasny: ponieważ nie można mówić o tymczasowości naszego przebywania na ziemi, bo historia zbawienia toczy się już od wieków, w związku z tym trzeba właściwie społecznie umiejscowić i nadać konkretne znaczenie władzy Kościoła i cesarstwa. Boże stworzenie kierowane jest przez dwie zasady w dwóch autonomicznych sferach: obszar kościelny uświęcony władzą hierarchii z papieżem na czele i obszar świecki, nad którym pieczę sprawuje cesarz/król. Bóg wyznaczył cesarzowi wyłącznie moc władczą w świeckiej strefie życia społecznego i z tej racji duchowni także winni posłuszeństwo i szacunek tejże władzy w sprawach, które do życia świeckiego się odnoszą. Zaś papieżowi, biskupom i kapłanom Bóg dał władzę szafarzy sakramentów i z tej racji w sprawach wiary należy im okazywać szacunek i posłuszeństwo. Jednakże, zauważa papież Gelazy I, cesarz, choć najdostojniejszy i najwyższy w godności, troszczy się tylko o sprawy doczesne, cielesne, zaś te, które są wieczne, odnoszą się do duszy i ducha. W związku z tym sam cesarz korzysta z posługi duchowej kapłanów i w sferze religijnej jest im podległy. Tak też to, co się odnosi do zbawienia i wieczności, pozostaje w gestii władzy kościelnej i tutaj cesarz musi uznać swoje poddaństwo.

Faktem jest, że obie władze współistnieją w tym samym czasie, obie podlegają i odpowiadają przed Bogiem, ale ich zakres oddziaływania i odpowiedzialności jest zgoła inny. Cesarz zajmuje się doczesnością i materialnością, i odpowiada tylko przed samym sobą, zaś papież dba o wieczność i przed Bogiem odpowiadać będzie nie tylko za siebie, ale także za cesarza. A skoro tak, to musi mieć jakiś wpływ i choćby minimalną władzę nad cesarzem. Obie też władze tworzą porządek społeczny, ale istnieją rozdzielnie i ich umocowanie jest inne. Pomiędzy nimi występuje hierarchiczna zależność, bowiem stan duchowny jest ważniejszy, gdyż realizuje ważniejszy cel aniżeli cesarz, dlatego też uzasadnione jest, by papież stał wyżej niż on (Lortz, 1987). 


\section{PODSUMOWANIE}

Przedstawiliśmy trzy warianty rozumienia władzy kościelnej i politycznej oraz ich relacji w średniowieczu. Pierwszy z nich - „euzebiański" - przesuwał akcent ważności i powagi władzy na cesarza, przypisując mu pewne boskie znamiona. Drugi „augustyński” jest zgoła przeciwny: to państwo Boże jest jedynie słuszne i władza kościelna, która tu na ziemi nim zawiaduje. I nawet jeżeli św. Augustyn dostrzegał wiele dobra i darzył szacunkiem władzę świecka, to jednak hierarchia ważności była tutaj jednoznaczna. I ostatni, trzeci wariant „ambrozjańsko-gelazjański”, który dostrzegał powagę zarówno władzy kościelnej, jak świeckiej i zaproponował ich rozdział i autonomię, ale we wzajemnej współpracy, mając na celu dobro ludzi i dobro wspólne.

Jedno dla wszystkich trzech wersji jest wspólne: bez względu na to, jaką władzę bardziej podkreślano czy uwielbiano, każda z nich darzyła wyjątkową estymą władzę świecka, uznając jej udział w całej historii zbawienia i dziejach ludzkości. Owe trzy warianty, szczególnie „ambrozjańsko-gelazjański”, wytyczyły pewien schemat podejścia do tego zagadnienia. Porządek świata tworzą trzy instancje, o których wspominaliśmy, a mianowicie: Bóg - źródło wszelakiej władzy, Kościół (mistyczne Ciało Chrystusa) - troszczy się o zbawienie człowieka i zajmuje przede wszystkim sferą duchową oraz cesarstwo - władza świecka, która stanowi swoje prawo i sprawiedliwość. Ten trójkąt "trójwładzy" naturalnie nie jest równoboczny i równokątny, bowiem Bóg jest źródłem wszystkiego, natomiast dwie pozostałe czerpią z Jego krynicy i od Niego biorą istnienie. Wszystkie one jednak tworzą całościowy układ. Naturalnie, problem pojawił się wtedy, kiedy próbowano odpowiedzieć na pytanie, jaką moc (ilościowo i jakościowo) czerpie od Boga Kościół i cesarstwo oraz jak te dwie władze winny współpracować i wiązać się ze sobą.

Wróćmy na koniec do próby odpowiedzi na postawione pytanie: dlaczego dzisiaj, dość powszechnie, nie szanuje się władzy, szczególnie w kulturze zachodniej, której fundamenty są iście chrześcijańskie? Rozważmy to w kilku punktach na podstawie tego, co do tej pory powiedzieliśmy:

a) „Nie ma bowiem władzy, która by nie pochodziła od Boga, a te, które są zostały ustanowione przez Boga" (Rz 13,1). 
Dzisiaj, w kulturze europejskiej coraz trudniej mówić o Bogu, a tym bardziej w Niego wierzyć, więc przypisywanie $\mathrm{Mu}$ źródła porządku w świecie i miłości do stworzeń nie znajduje słusznych racji. Zamykanie się na Transcendencję współczesnego człowieka prowadzi do zubożenia immanencji i w konsekwencji do neopogaństwa (Pasierbek, 2018).

b) „Ponieważ władza pochodzi od Boga, należy jej słuchać, tak jak winniśmy posłuszeństwo samemu Bogu, bo władza jest narzędziem, które ma ułatwiać czynienie dobra, a chronić przed złem" (Rz 13,5). Jako że władza pochodzi od Boga, który przez Wcielenie Jezusa Chrystusa przywrócił porządek w świecie chaosu zapoczątkowanego w raju, dlatego celem władzy jest wprowadzanie porządku, pokoju i troski o dobro wspólne. Jeżeli jednak za prawdziwe i dobre przyjmujemy tylko to, co według nas jest racjonalne i sprawdzalne empirycznie, wówczas przyjmowanie czegoś, co stanowi „dobro wspólne", jest tylko i wyłącznie arbitralną decyzją jednostki, przez co istnieją tzw. "dobra partykularne”, a nie „wspólne”. A skoro tak, to władza, która "ma ułatwiać czynienie dobra”, jest zbędna.

c) Władzy należy słuchać, „, ale ze względu na sumienie” (Rz 13,5). Umiejętność właściwej oceny moralnego postępowania człowieka zależna jest od formacji, kształtowania tegoż sumienia. Stąd też, jak słusznie twierdził I. Kant, Bóg jest takim „moralnym Sędzią”, u którego winniśmy szukać tej właściwej oceny, także w stosunku do władzy. Kierowanie się zaś sumieniem to nic innego jak kierowanie się „,zdrowym rozsądkiem”, czyli rzetelnym "rozsądzaniem”.

Wydaje się zatem, że te trzy elementy: wiara, dobro wspólne i sumienie winny tworzyć prawdziwe społeczeństwo demokratyczne, wspólnotę obywatelską. Tak przynajmniej wynika z nauki pierwszych wieków nowej, chrześcijańskiej ery, a wówczas szacunek i posłuszeństwo władzy będzie czymś naturalnym. 


\section{Bibliografia}

Augustyn (1977). O państwie Bożym: przeciw poganom ksiag XXII, t. 1 i 2. Przeł. W. Kornatowski. Warszawa: Instytut Wydawniczy PAX.

Brown, P. (1992). Power and Persuasion in Late Antiquity. Towards a Christian Empire. Wisconsin: The University of Wisconsin Press.

Daniélou, J. i Marrou, H.I. (1986). Historia Kościoła, t. I. Warszawa: Instytut Wydawniczy PAX.

Lortz, J. (1987). Storia della Chiesa in prospettiva di storia delle idee, vol. I. Milano: Edizioni Paoline.

Majka, J. (1987). Katolicka Nauka Społeczna. Rzym-Lublin.

Papieska Rada Iustitia et Pax (2005). Kompendium Nauki Społecznej Kościoła. Kielce: Wydawnictwo Jedność.

Pasierbek, W. (2018). U podstaw sekularyzacji: przyczyny filozoficzno-teologiczno-kulturowe z aspektem edukacyjnym. Horyzonty Polityki, 9(27).

Scattola, M. (2011). Teologia polityczna. Warszawa: Instytut Wydawniczy PAX.

Sobór Watykański II (1967). Konstytucja o Kościele w świecie współczesnym. Poznań: Pallottinum.

\section{Copyright and License}

This article is published under the terms of the Creative Commons Attribution - NoDerivs (CC BY- ND 4.0) License http://creativecommons.org/licenses/by-nd/4.0/ 